31 (4) : 295 299, 1981

\title{
石灰乳胆汁の 2 治験例
}

\author{
六本木 隆, 饗 場 庄一, 塩崎秀 郎 \\ 松本弘, 佐藤晴男, 桜井達夫 \\ 中島博, 仲村匡也, 金子達夫 \\ 前橋赤十字病院 外科
}

(昭和56年 6 月 8 日 受付)

\section{はじめに}

石灰乳胆汁についての記載は Johns-Hopkins 大 学の Churchmann ${ }^{1)}$ に始まる。彼は1911年, 急性胆

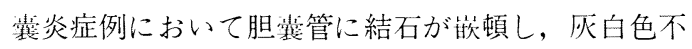

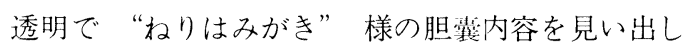
“calcium soap” と表現した。 その後1926年 Volkmann" が “kalkmilchartige Galle” と言う表現で2 例報告，1933年 Knuttson" は “limy bile” と表現し ている。

本症は本邦では稀な特異的存在とされてきたが既 に230例程が報告されている.しかし胆装摘出患者の 数から見れば少ないことは確かである。本症の特徵 を知ることによって術前診断が可能である. 前橋赤 十字病院外科での最近 10 年間の胆丵摘出総数 434 例 中 2 例 $(0.46 \%)$ の本症を経験したので報告すると ともに文献的，統計的な検討を加えた。

\section{症例 1}

松○茂○, 24歳, 女性

昭和 48 年 5 月上腹部と背部の疼痛があり胆襄造影 と胃透視を受けているが異常を指摘されていない。 その後 9 月, 11 月にも同様の疼痛があったが投薬の みの治療を受けた。昭和 49 年 1 月疼痛発現し, 当院 外科に入院した。入院時の検查所見では貧血，白血 球増多なく肝機能も正常範囲である，尿所見にても 異常を認めない。

DIC にては総胆管は造影されず，胆壸は萎縮性で 造影されているというよりは胆露内に液状の陽性像 があり頸部には結石と思われる陰影を認女る所見で ある(図 1 )。

胃透視にても体位によって変わる陽性㓌影を認め る(図2, 3).

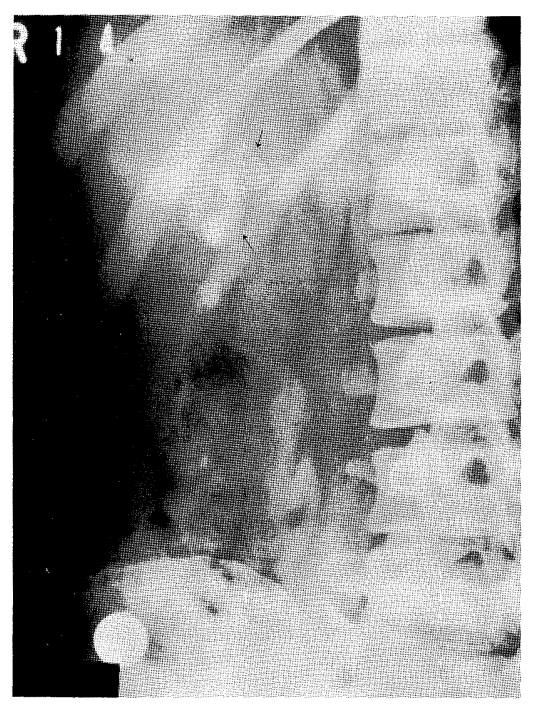

図 1 症例 $1 の$ DIC

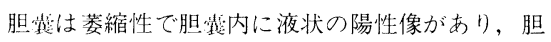
霍頸部には結石㓌影を認める。

昭和49年 3 月 28 日胆石症として胆囊摘出術を施行 した。摘出標本は図 4 の如く胆雪頸部にコレステリ ン結石の嵌入があり，胆素内にも多くの結石を認め た。胆露の内容はのり状の石灰乳である。

\section{症例 2}

角○や○い, 25歳, 女性

3〜 4 力月来夜間上腹部の激痛が時々あり, 鎮痛 剂の投与を受けていた。昭和54年11月 3 日，当院内 科にて DIC を施行. 胆石症の診断にて外科入入院し た。

入院時の検查所見では貧血, 白血球増多はないが, 総ビリルビン $2.8 \mathrm{mg} / \mathrm{dl}$ 直接ビリルビン $1.7 \mathrm{mg} / \mathrm{dl}$, 


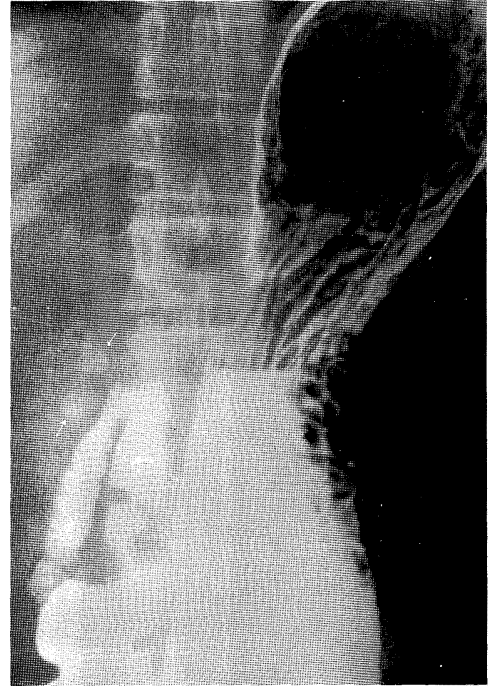

図 2 症例 1 の胃透視

胆独部に一致して陽性像を認める。

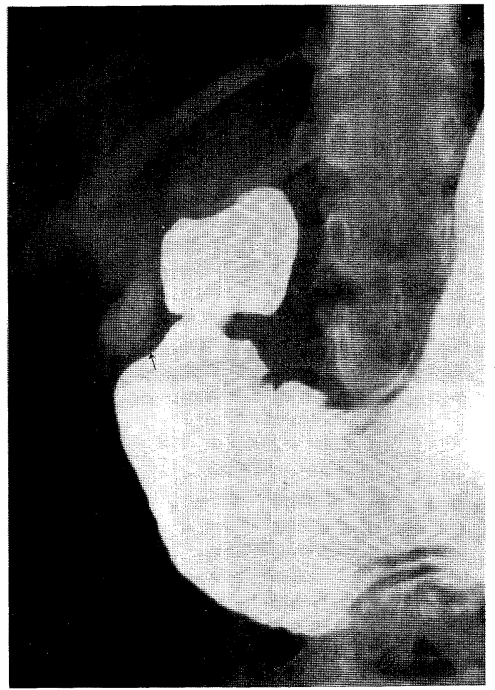

図3 症例 1 の胃透視

胆萝部の陽性像は体位によって形を変える。

アルカリフォスファターゼ12.6K.A.U., GOT 135, GPT 354 と高值を示した。カルシウムや他の電解質 は正常である。

DICにては胆裳底部に数コの結石, 頸部に $3 \sqsupset の$ 結石を認め(図 5 ), 断層撮影にて総胆管内にも結石 の存在が疑われた（図6).

胃透視のレ線写真にては，胆露部分に不定形の陽

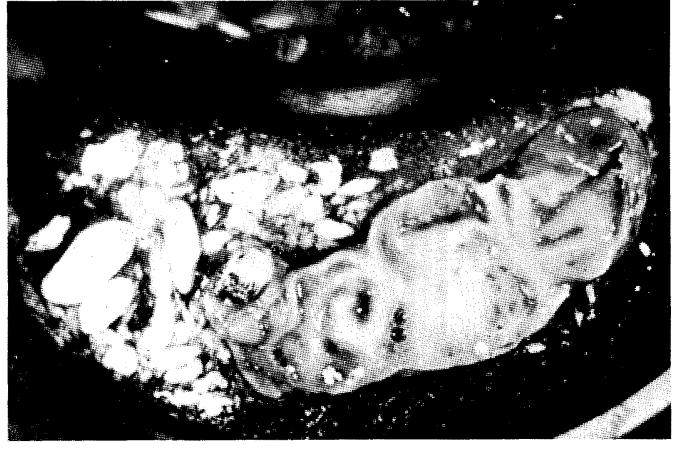

図 4 症例 1 摘出標本

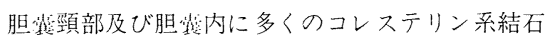
を認め，胆螸内容はのり状の石灰乳である。

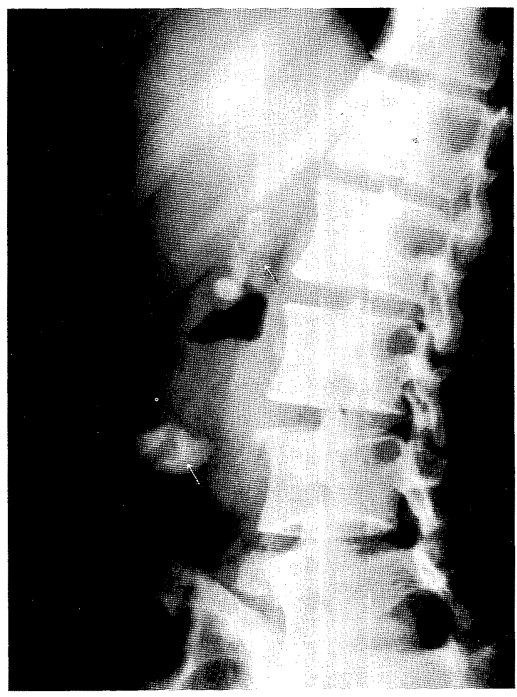

図 5 症例 2 の DIC

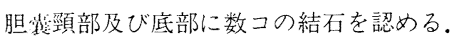

性像とともに結石院影も認める（図７）.

超音波所見では胆灌頙部に結石エコーを認め，さ らに胆粪内に輝度が高い不定形のエコーと媣部工 コーの減衰を認め, 術前より石灰乳胆汁を合併した 胆石症と診断できた。

手術所見では，胆鞳内に小豆大から米粒大の 5 コ のビリルビン結石と淡緑色の石灰乳胆汁 $5 \mathrm{cc}$ あり 頸部に結石が1コ嵌入（図 8 ).

総胆管内にも 2 コの小結石があり，その 1 コが下 部総胆管に卉入していたので，経十二指腸的に乳頭 形成術を行った。

症例 $1 \cdot 2$, ともに化学分析を行った結果, 炭酸 


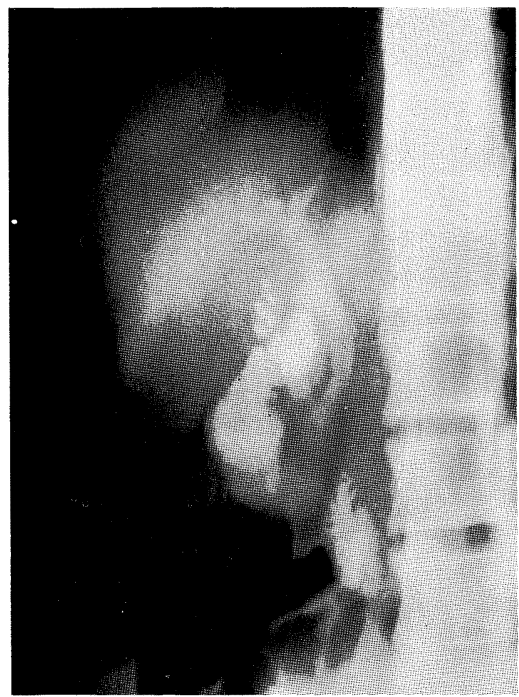

図 6 症例 2. DIC の断層撮影 総胆管内にも結石㓌影認める.

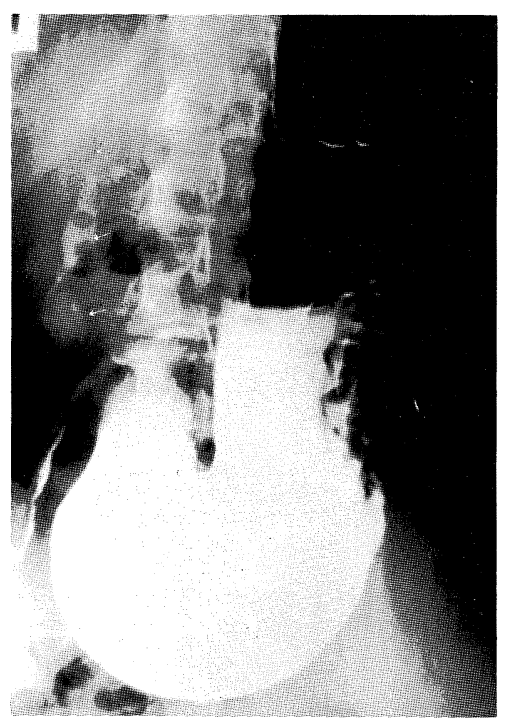

図 7 症例 2 の胃透視

胆䔮部分に陽性像と結石㓌影を認める。

カルシウムが主成分で結晶形は aragonite であった (群馬大学工学部分析化学教室赤石英夫教授によ る).

\section{文献的考察}

表 1 の如く石灰乳胆汁の発生頻度は少なく, Phemister $^{4)}$ らは313例中 4 例 $(1.3 \%)$ と報告, 本邦

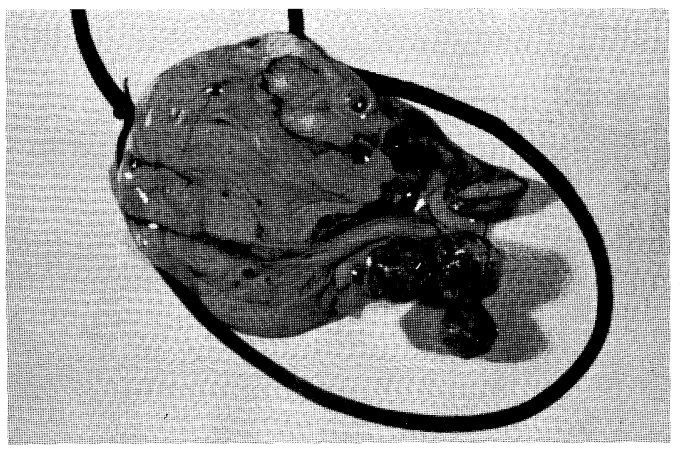

図 8 症例 2 の摘出標本

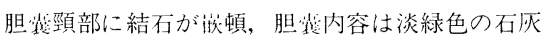
乳胆汁である。

表 1 胆石症手術例に対守る石灰乳胆汁例の頻度

\begin{tabular}{|c|c|c|c|}
\hline 報 告 者 (年) & 䏣石症手術 & 石灰釈䏣汁例 & 頪度 $(\%)$ \\
\hline Phemister & 313 & 4 & 1.3 \\
\hline 松井ら（名大内科） & 360 & 2 & 0.6 \\
\hline 村上ら(大阪海生年金病院外科)(1970) & 677 & 7 & 1.0 \\
\hline 山口ら（東医歯大1外）（1974） & 706 & 16 & 2.3 \\
\hline 周村ら (泉大津市民病外科)(1974) & 59 & 2 & 3.4 \\
\hline 宫崎ら(国立下咸病外科)（1976） & 179 & 3 & 1.7 \\
\hline 中属的（畏崎大 1 外） & 227 & 3 & 1.3 \\
\hline 小林的（李林大放紂線）（1978） & 175 & 2 & 1.1 \\
\hline 饗場ら（前楉日赤外科）（1980） & 434 & 2 & 0.46 \\
\hline
\end{tabular}

表 2 石灰乳胆汁症例の年齢分布と性別頻度

\begin{tabular}{|c|c|c|c|}
\hline 年令(才) & 男 & 女 & 計，\%) \\
\hline$\sim 19$ & 0 & 4 & $4(1,9)$ \\
\hline $20 \sim 29$ & 6 & 22 & $28(13.0)$ \\
\hline $30 \sim 39$ & 18 & 41 & $59(27.3)$ \\
\hline $40 \sim 49$ & 20 & 35 & $55(25.5)$ \\
\hline $50-59$ & 17 & 30 & $47(21.8)$ \\
\hline $60 \sim 69$ & 2 & 18 & $20(9.3)$ \\
\hline \multirow[t]{2}{*}{$\sim 70$} & 1 & 2 & $3(1.4)$ \\
\hline & 64例 & 152例 & 216 例 $\left(100^{\circ} o\right)$ \\
\hline
\end{tabular}

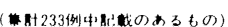

では1970年村上5) らは677例中 7 例 (1\%) と報告し ている。われわれの施設では433例中 2 例 $(0.46 \%)$ であった. 1980年 8 月現在の本邦集計216例では, 男 64例，女152例で男女比は $1: 2.4$ で女性に多く，胆 石症と同様の傾向が見られ，年齢では最年少 1 歳, 最年長72歳で30～40歳台に多く見られた（表 2 ）。

本症の臨床症状は胆石症, 慢性胆雯炎とほぼ同様 で, 上腹部痛, 右季助部痛を土訴とするものが多く, 
総胆管結石を合併しない限り，黄疸を見ることは稀 であり発熱も少ない。

診断は, 腹部単純レ 線像で, 三力月状, 半月状, 胆囊様など，体位によって変わる不定形の陽性像が 特徵的で, それには胆囊内石灰乳胆汁の量, 比重(濃 縮の程度), 胆囊炎の程度, 結石の合併等が大いに関 与している。DICにて総胆管が造影されないにもか かわらず常に一定の濃度で胆霅が造影されたり（症 例 1 ), 胃透視の際に胆嚷の位置に一致して陽性像を 見たりするが（症例 1，2）いずれも看過されやす いと思われる。まず腹部単純写真を撮るべきである j.

超音波検査では，胆囊頸部に結石エコーを認め胆 囊内には深部エコーの減衰を伴う輝度の高いエコー を認める。深部エコーが消失しない点で結石エコー と異なる所見である。

成因

成因については古くより論議されてきたが，(1)胆 囊管の閉塞, (2)軽度の慢性胆霅炎, (3)胆霊内胆汁の $\mathrm{pH}$ がアルカリ性に傾くこと,の 3 点が重要な因子 と考えられている.

症例を検討してみると，胆囊頸部，胆霅管への結 石の嵌頓が注とんどであるが, 他に胆囊管周辺のリ ンパ節腫大による胆囊管の圧迫，(川上） ${ }^{6)}$, 胆囊管 の瘷痕性閉塞 $(\text { 黑田 })^{7)}$, 胆囊癌 $\left(\right.$ Whipple $e^{8)}$, 谷井 $\left.{ }^{9}\right)$ 胆囊頸部囊胞による胆囊管の圧迫 $\left(\mathrm{P}^{\circ}\right.$ 馬ら $\left.{ }^{10)}\right)$ など によって，胆霅内に胆汁がうっ滞し，それに加之軽 度の慢性胆霊炎の合併により, 胆囊壁よりカルシウ ムが分泌されるとする説 $\left(\right.$ Phemister $\left.{ }^{11}\right)$, 胆囊粘膜の 吸収能の低下とあいまってカルシウム結晶が沈港す るとの説 $\left(\right.$ Aschoff $\left.^{12)}\right)$, 胆囊内胆汁のコレステリン, 胆汁酸が減少し $\mathrm{pH}$ が上昇することによりカルシウ ムイオンが結晶化し沈澱してくる(Mc.Call $\left.{ }^{13)}\right)$ との 説など種々論議されてきたが, 本邦においては, 梖 ${ }^{14)}$ らが, 胆囊内回虫屍に炭酸カルシウムの沈着がおこ る実験的事実から，胆汁うっ滞と慢性炎症により腐 敗現象をひきおこし, 胆囊内に炭酸アンモニウムが 発生して $\mathrm{pH}$ がアルカり性に傾くことによりカルシ ウムと置換され, 炭酸カルシウムの結晶が沈澱して くると説明している。その他, 胁軟骨早期化骨, 血 中カルシウム高值, 尿中カルシウム排泄増加の症例 を経験してカルシウム代謝異常と関連づけた例 $\left(\mathrm{Green}^{15)}\right)$ や, 胆汁の異常組成に因を求为, 肝代謝 異常と関連づけた例 $\left(\right.$ Kreuscher $\left.^{16)}\right)$ などがある.
石灰乳胆汁は，その形態により

(1) 薄い乳状の液体

(2) 柔かい糊状物質

(3) 粘性，可塑性のあるゴム様物質

(4) 白墨様結石

の4つに主に大別しているが，これは胆雚の濃縮力， 及び経過時間により，それぞれの硬度に至ると考え られる $\left(\operatorname{Berg}^{17)}\right)$.

結語

石灰乳胆汁の本邦における報告は既に230例程み られるが胆石症の手術例数からみれば極く稀であ る. 前橋赤十字病院で10年間に扱った胆囊摘出患者 数は434例でこの間に 2 例 $(0.46 \%)$ の本症（24歳女 性，25歳女性）を経験した。レ線写真などから術前 診断が可能と思われる。2 例の化学分析の結果主成 分は炭酸カルシウムで結晶形は aragonite であっ た。本症の文献的・統計的な検討を行った。

\section{文献}

1) Churchmann, J.W. : Acute Cholecystitis with large amount of calcium soap in the gall bladder. Johns. Hopk. Hosp. Bull., 22 : 223, 1911.

2) Volkmann, J. : Über kalkmilchartige Galle. Münch. Mediz., 48 : 2014, 1926.

3) Knuttson, F.：槇 哲夫：石灰乳胆汁の成因 についての一考察。外科, $26: 273,1964$ より引 用.

4) Phemister, D.B. et al. : Calcium carbonate gallstones and calcification of the gallbladder following cystic duct obstruction Ann. Surg., 94:493, 1931.

5）村上栄一郎，ほか.：石灰乳胆汁について一 自験例 7 例の検討と考察一. 外科治療, $23: 703$, 1930

6）川上良澄，ほか。：石灰乳胆汁の一例. 北野 病院紀要, 9:182, 1964.

7) 黒田栄一：石灰乳胆汁の一例. 交通医学, 17: 449, 1964.

8) Whipple, : Phemister, D.B. : Calcium carbonate gallstones and their experimental production. Ann. Surg., 96 : 595, 1932より引用.

9）谷井東助ほほ：：石灰乳胆汁を伴った胆囊 
管癌の一例。福島医誌，16：482，1966.

10）門馬公経，ほか。：石灰乳胆汁を伴った極め て稀な胆湮頸部槕胞の一手術例。日消外会誌, $14: 439,1981$.

11) Phemister, D.B., et al. : Calcium carbonote gallstones and calcification of the gallbladder following cystic duct obstruetion. Ann. Surg., $94:$ 493, 1931.

12) Aschoff.：村上栄一郎, ほか. : 石灰乳胆汁に ついて一自験例 7 例の検討と考察一, 外科治療, $23: 703,1970$. より引用.
13）Mc. Call.：槇 哲夫：石灰乳胆汁の成因につ いての一考察。外科, $26: 273,1964$ より引用。

14）槇 哲夫：石灰乳胆汁の成因についての一考 察. 外科, $26: 273,1964$.

15) Green, N.A. : A case of "limy bile" causing obstructive jaundice. Brit. J. Surg, $47: 222$, 1959.

16) Kreuscher, H. : Ein Beitrag zum Thema Kalkmilchgalle. Zbl. Chir., 82 : 1195, 1957.

17) Berg, J. : Zur Diagnose der "Kalkgalle." Fortschr. Röntgenstr., 60 :284, 1939.

\section{TWO CASES OF "LIMY BILE"}

\section{TAKASHI ROPPONGI, SHOICHI AIBA, HIDEO SHIOZAKI \\ HIROSHI MATUMOTO, HARUO SATO, HIROSHI NAKAGIMA, TATUO SAKURAI, MASAYA NAKAMURA, TATUO KANEKO,}

Maebashi Red Cross Hospital, Maebashi, Japan.

According to previous literature, about 230 cases of "limy bile" have been represented by 1980 in Japan.

But it is extremely rare to find the "limy bile" cases in a lot of the operative cholelithiasis.

In our hospital, 434 cases have been diagnosed cholelithiasis and operated in the past ten years., in these, we have experienced two cases of "limy bile" (A 24-year old female and a 25 year old female) $(0.46 \%)$.

It is possible to diagnose "limy bile" preoperatively by means of radiological findings and ultrasonography.

Two cases were presented and literal study were added.

Key words : Limy bile, Cholelithiasis 